OPEN ACCESS

Edited and reviewed by:

Liam Chen,

Johns Hopkins University,

United States

*Correspondence:

Paul Dent

paul.dent@vcuhealth.org Laurence Booth

laurence.booth@vcuhealth.org

Specialty section:

This article was submitted to Neuro-Oncology and Neurosurgical

Oncology,

a section of the journa

Frontiers in Oncology

Received: 11 March 2020

Accepted: 14 April 2020

Published: 30 April 2020

Citation:

Dent P, Booth L, Roberts JL, Poklepovic A and Hancock JF (2020) Corrigendum: Fingolimod Augments Monomethylfumarate Killing of GBM

Cells. Front. Oncol. 10:684

doi: 10.3389/fonc.2020.00684

\section{Corrigendum: Fingolimod Augments Monomethylfumarate Killing of GBM Cells}

\author{
Paul Dent ${ }^{1 *}$, Laurence Booth ${ }^{1 *}$, Jane L. Roberts ${ }^{1}$, Andrew Poklepovic ${ }^{2}$ and \\ John F. Hancock ${ }^{3}$ \\ ${ }^{1}$ Departments of Biochemistry and Molecular Biology, Virginia Commonwealth University, Richmond, VA, United States, \\ ${ }^{2}$ Departments of Medicine, Virginia Commonwealth University, Richmond, VA, United States, ${ }^{3}$ Department of Integrative \\ Biology and Pharmacology, University of Texas Health Science Center, Houston, TX, United States
}

Keywords: fingolimod, dimethyl fumarate, Gilenya, Tecfidera, RAS, glioblastoma, microglia

\section{A Corrigendum on}

Fingolimod Augments Monomethylfumarate Killing of GBM Cells by Dent, P., Booth, L., Roberts, J. L., Poklepovic, A., and Hancock, J. F. (2020). Front. Oncol. 10:22. doi: $10.3389 /$ fonc.2020.00022

In the original article, there was a mistake in Figure 7C as published. By error, the image for FAS$\mathrm{L}$ treated with MMF was included twice; once correctly and once as FAS-L treated with vehicle control. The corrected Figure 7C for FAS-L assessments appears below.

The authors apologize for this error and state that this does not change the scientific conclusions of the article in any way. The original article has been updated.

Copyright (C) 2020 Dent, Booth, Roberts, Poklepovic and Hancock. This is an open-access article distributed under the terms of the Creative Commons Attribution License (CC BY). The use, distribution or reproduction in other forums is permitted, provided the original author(s) and the copyright owner(s) are credited and that the original publication in this journal is cited, in accordance with accepted academic practice. No use, distribution or reproduction is permitted which does not comply with these terms. 


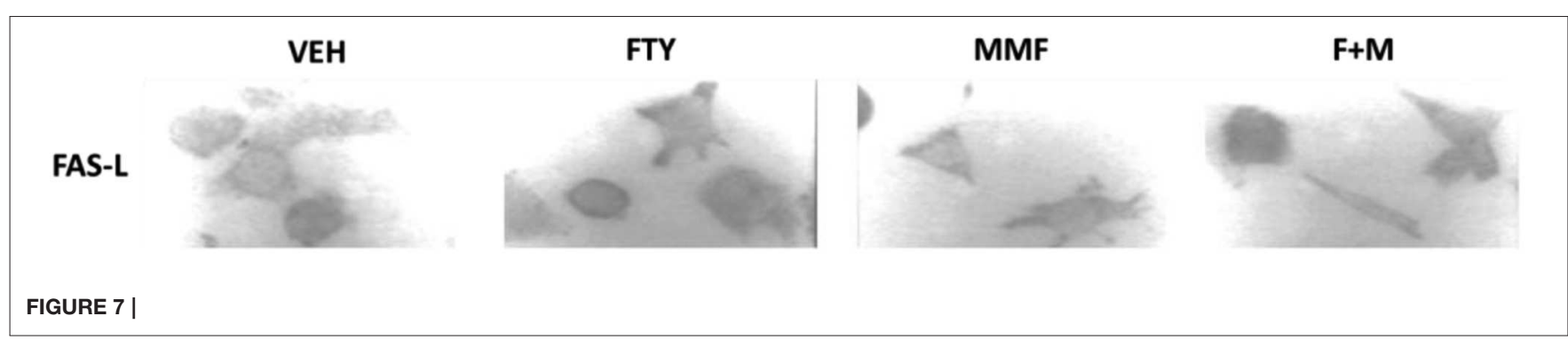

